原発性前立腺扁平上皮癌の 1 例

\begin{tabular}{ccccc} 
名鉄病院泌尿器科 & 岡 & 村 & 菊 & 夫 \\
& 伊 & 藤 & 浩 & 一 \\
名古屋大学泌尿器科教室 & 佐 & 橋 & 正 & 文 \\
\cline { 2 - 3 } & 下 地 & 敏 & 雄
\end{tabular}

\title{
PRIMARY SQUAMOUS CELL CARCINOMA OF THE PROSTATE: A CASE REPORT
}

\author{
Kikuo Okamura and Koichi Ito \\ Department of Urology, Meitetsu Hospital, Nagoya, Japan \\ Masahumi Sahashi and Toshio Shimoji \\ Department of Urology, Nagoya University School of Medicine
}

A case of squamous cell carcinoma of the prostate is reported. This form of the prostatic cancer is extremely rare and has a poor prognosis.

A 59-year-old man who complained of dysuria underwent transurethral resection. Histological diagnosis was squamous cell carcinoma. Radical prostatectomy was performed but he died 8 months after operation.

要旨：原発性前立腺扁平上皮癌は，極めて稀であり，本邦では，現在までに 3 例が報告されているにす ぎない。また本症の予後は不良であるとされている。

本症例は，59歳の男性で排尿困難・尿閉を主訴に受診した。前立腺肥大症の診断下に，経尿道的前立 腺切除術が施行され，病理組織学的に扁平上皮癌と診断された。 2 カ月後前立腺全摘術及びリンパ節郭 清術を施行した。リンパ節転移に対し，放射線療法を扣こなったが，局所に再発し，初診より10カ月後 に死亡した。

\section{緒 言}

前立腺癌の漂とんどは腺癌であり，原発性前立腺扁 平上皮癌は稀である。我々は最近本症の 1 例を経験し たので，文献的考察を加えて報告する。

症例

患者：阪 $\bigcirc$ 隣 $\bigcirc ， 59$ 歳，男性

主訴：排尿困難，急性尿閉

既往歴：䯣膜炎。下肢血栓静脈炎

家族歴：特記すべきことなし

現病歴：1982年 2 月頃より排尿因難, 残尿感があっ たが，6月15日急性尿閉となり近医にてカテーテルを 留置された。当院を紹介され 6 月22日当科外来を受診 した。

現症：体格中等度。栄養良好。胸部，腹部に異常な く, 肝。脾・腎は触知せず。単径部リンパ節触知せず. 辠丸・副殬丸・陰茎は正常. 直腸内触診では，前立腺 は鶏卵大。弾性硬よりはやや硬いが表面不整はなく境
界は明瞭であった。

入院までの経過：初診時混濁尿あり。蛋白 $(+)$, 潜 血 (H), 糖 (一)，カテーテル留置に伴なら尿路感染 症を合併していると考えられたため, SMX-TMP を投 与した。6 月23日の DIP にて, 上部尿路に特に異常を 認めないが, 右側尿管はやや内側に偏位していた(Fig. 1)。UCG では後部尿道の廷長及びやや不整な膀胱底部 を認めた。しかし後部尿道壁の異常は認めなかった (Fig. 2)。以上より，前立腺肥大症と診断し，7月2日 手術のため入院となった。

入院時検查成績：尿沈渣 RBC $40 \sim 50 / \mathrm{hpf}, \mathrm{WBC}$ $8 \sim 10 / \mathrm{hpf}$ ，尿培養陰性．末梢血一般 RBC $417 \times 10^{4}$, WBC 5400 , Ht $37.5 \%, \mathrm{Hb} 12.8 \mathrm{~g} / \mathrm{dl}$ ，血小板 $15.1 \times$ $10^{4}$ 。血液生化学検查, 血清総蛋白 $7.2 \mathrm{~g} / \mathrm{dl}, \mathrm{A} / \mathrm{G}$ 比 1.02 , BUN 17.1mg/dl, Creatinin 1.25mg/dl, GOT 21単位, GPT 19単位, LDH 261単位, ALP 1.58 Bessey-Lowry 単位，酸性フォスファターゼ 0.55 Bessey-Lowry 単 
Fig. 1 DIP shows the bladder base elevation and medial deviation of r-ureter

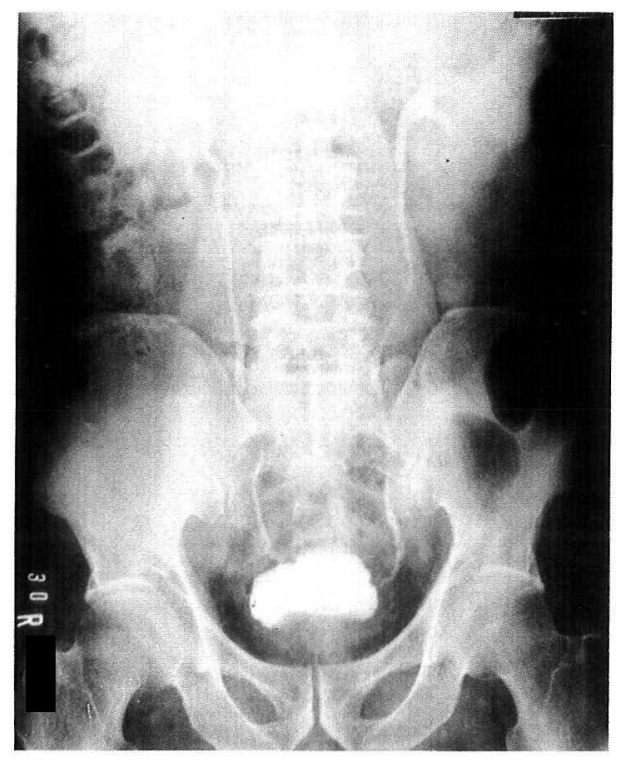

Fig. 2 UCG demonstrates elongation of the posterior urethra



位。胸部X線写真, 心電図ともに異常ない。

入院後の経過：7月 5 日硬膜外麻酔下に TUR-Pを 施行した。切除鏡乗入はやや困難であった。切除重量 $12 \mathrm{~g}$. 切片はもろく前立腺癌が疑われた。な搒胱内に
Fig. 3 Histological appearance of TUR specimen

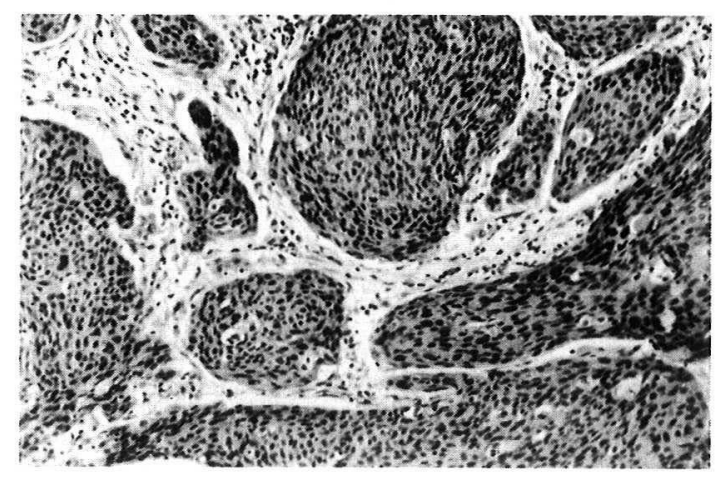

Fig. 4 Lymphangiography shows metastasis beyond the aortic bifurcation

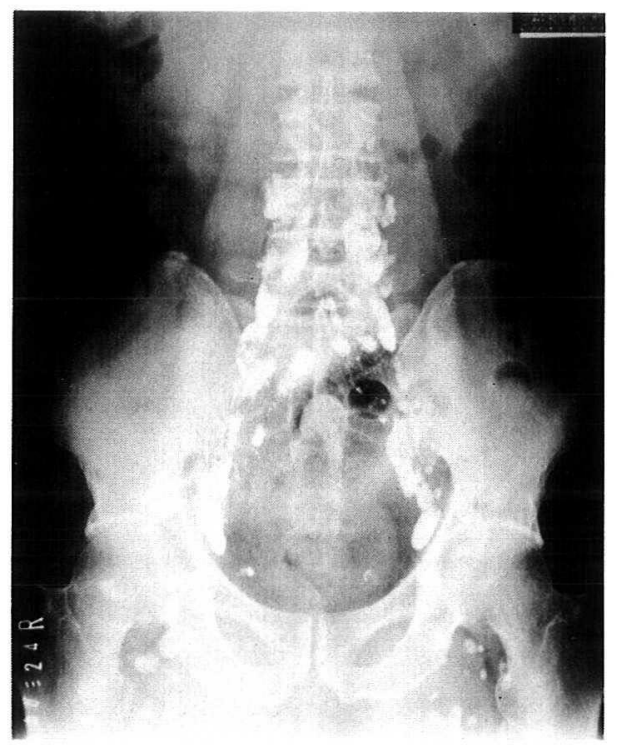

は腫瘍を認めなかった。

病理所見は，角化を伴なら扁平上皮癌で squamous pearl や intercelluler bridge を認めたが，腺癌の像は みられなかった (Fig. 3)。

肝・骨シンチグラムでは遠隔転移は認められなかっ たが，リンパ管造影では腹部大血管分岐部を越える転 移を認めた（Fig. 4)。

超音波検査では，前立腺被膜を越兄ての癌浸潤はな いと思われた（Fig. 5)。

7 月 30 日去勢術施行後, 9 月 1 日前立腺全摘術及び リンパ節郭清術を施行した。前立腺摘出重量は $52 \mathrm{~g}$ て あった (Fig. 6). 所属リンパ節には左右ともに広汎な 
Fig. 5 Ultrasonography of the prostate seems to demonstrate no tumor invasion beyond the capsule
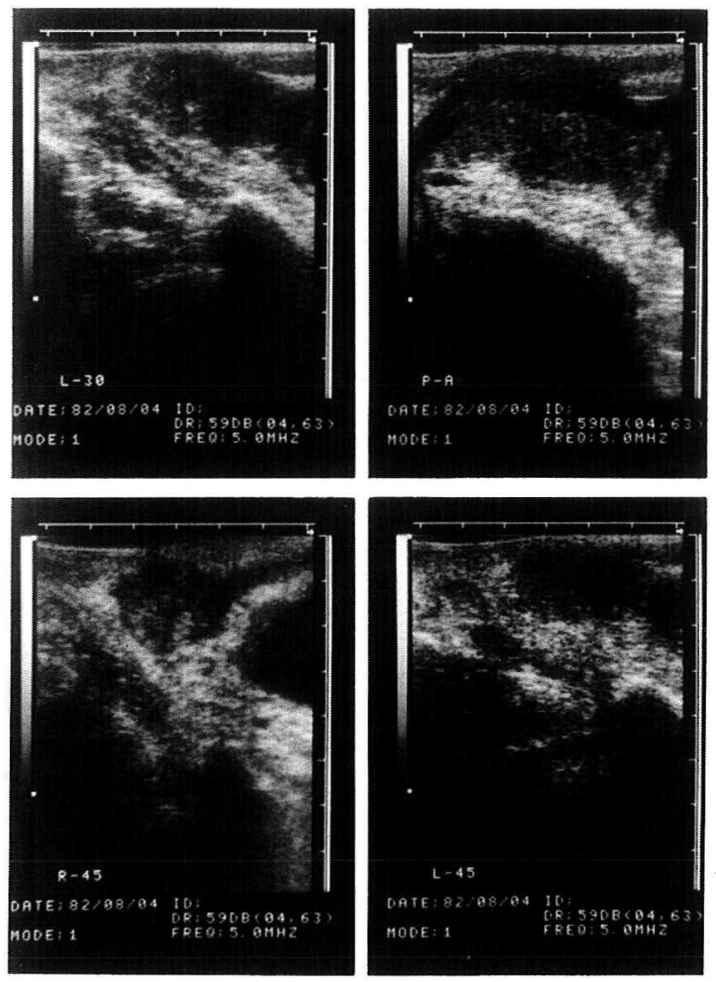

Fig. 6 Gross appearance of the extirpated prostate

S.V. Seminal vesicle Veru. Verumontanum

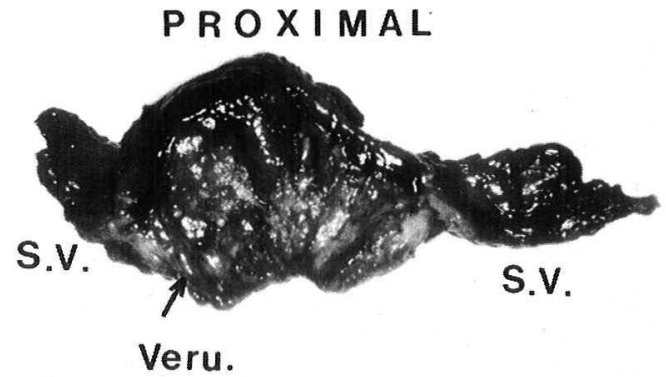

DISTAL 治癒切除は望めなかったため郭清は腹部大血管分岐部 までとした。
Fig. 7 High grade squamous cell carcinoma

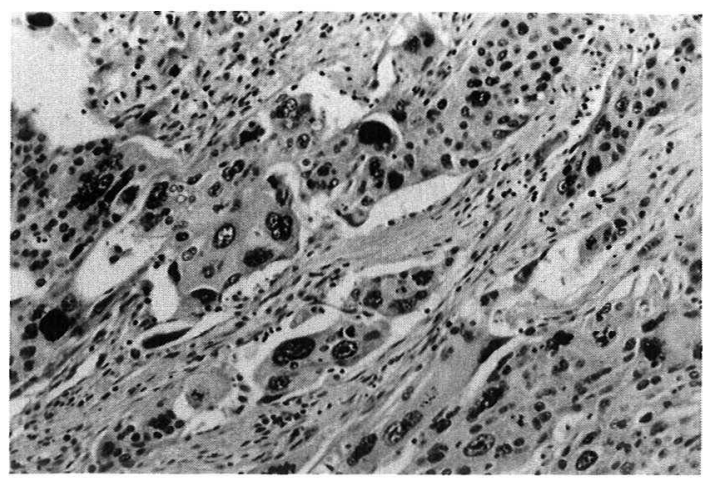

Fig. 8 Undifferentiated carcinoma

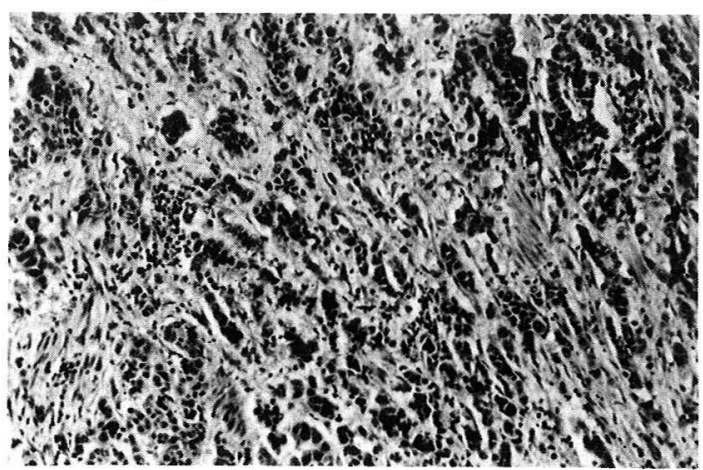

摘出標本の組織学的所見：内腺はほとんど癌組織に 扣きか兄られて扣り一部被膜にまで浸潤していた。外 腺組織は菲薄化していたが腺房構造はよく保たれてい た。癌組織は比較的よく分化した扁平上皮癌の部分と 異型度の強い扁平上皮癌の部分 (Fig. 7) より成ってい たが，一部には，やや小型で異型の強い細胞が乳嘴状 や蜂窠状の構造をとりながら浸潤増生している未分化 癌（Fig. 8）が認められた。

9 月28日より所属リンパ節及び旁大動脈リンパ節に 対し総量5,000rad を逆Y照射した。1983年 1 月 5 日尿 道出血があり，直腸診・尿道鏡にて局所再発認め, DIP にても両側水腎症を認めたため1月21日尿管皮膚瘻を 造設した。その後イレウスとなり 3 月 22 日糞瘦造設術 を施行したが，次第に悪液質の状態となり 5 月 1 日死 亡した。

\section{考察}

原発性前立腺扁平上皮癌は極めて稀なものであり， 本邦に执いては現在までに 3 例の報告をみるにすぎな (1) 4)（Table 1）。外国文献によると発生頻度は 0 
Table 1 前立腺扁平上皮癌の本邦例

\begin{tabular}{|c|c|c|c|c|c|}
\hline & 報告者 & 年令 & 主 訴 & 治 療 & 経 過 \\
\hline 1 & 河崎屋 5 & $65 才$ & 排尿困難 & 抗男性ホルモン䇑法 & $\begin{array}{l}\text { 症状初発より } 6 \text { 力月 } \\
\text { 歹亡 }\end{array}$ \\
\hline 2 & 畑 & 71才 & 尿 & $\begin{array}{l}\text { TUR及び } \\
\text { ペプロマイシン }\end{array}$ & 初猃より 3 カ月生存 \\
\hline 3 & 佐々木ら & 78才 & 排尿困難 & $\begin{array}{l}\text { 抗男性ホルモンßひ } \\
\text { ブレオマイシン }\end{array}$ & 明 \\
\hline 4 & 自 験 例 & $59 才$ & 排尿困難 & 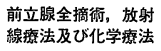 & $\begin{array}{l}\text { 症状初発より } \\
1 \text { 年 } 3 \text { 力月で死亡 }\end{array}$ \\
\hline
\end{tabular}

～3\%と報告によりひらきがあるが5) 7)，Mott らは $0.5 \sim 1 \%$ 妥当な数字であり, アメリカでは年間 300 ６00例の前立腺扁平上皮癌があるのではないかと 述べそれほど稀なものではないとしている8)。

本症の診断にはいくつかの困難を来す点がある。前 立腺に打ける腺上皮は梗塞や，TUR，あるいは尿路感 染症に伴ない扁平上皮化生を抬こすことがあり，これ を扁平上皮癌と誤ることがあるとされる9)。 また通常 の前立腺癌に対し抗男性ホルモン療法を行らと, 同様 の化生がひき扣こされる。それゆ光原発性前立腺扁平 上皮癌の診断のためには,

1. 角化を伴なら悪性腫痬で squamous pearl intercelluler bridge を認めること

2. 腺癌の形態を示す部のないこと

3。抗男性ホルモン療法をらけていないこと

4. 膀胼など他の部に原発性扁平上皮癌のないこと などの criteria を満たす必要がある。本症例において は上記 4 つの criteria をすべて満たした。

本症は診断時に扔いてすでに advanced stage にあ ることが多く明確な発生母地は指摘できない.5)。近年 prostatic duct 由来の移行上皮癌や腺癌が報告されて 打り ${ }^{10) 11)}$, 本症に扮いて子 duct に打ける移行上皮細胞 や reserve cell が発生母地として考兄られるが，尿道 癌の前立腺浸潤の可能性もあり, あるいは扁平上皮化 生を抗こした前立腺腺上皮より発生したとも考光られ る。

腺上皮由来ならば，原則的には血清酸フォスファ ターゼは高く, 抗男性ホルモン療法が効果を示す可能 性があるが，本症に拈いては血清酸フォスファターゼ は正常で抗男性ホルモン療法は無効であるとされてい る。又, Kahlerは acinus における metaplasiaはょく みられるのに対し扁平上皮癌は稀であることから acinus 由来之いうのは否定的で前立腺部尿道の移行 上皮より生じるのであろらと述べて拈り, Thompson
らも賛意を表している ${ }^{12)}$ 。尿道粘膜を発生母地とする ならば厳密には前立腺原発とはいい難いが，文献的に は前立腺内に癌が特異的に浸潤増生したものを原発性 として扱っているよらである，本症例では，病変の進 展様式から考えると, 尿道か尿道近傍の導管に原発し たものと括もわれたが，それ以上は不明である。

本症は，通常の前立腺癌と同様の年齢層に生じる. Mott は平均63歳と報告し, 本邦の 4 例の平均年齢は 68歳であった。初発症状としては排尿困難がもっとも 多い。

本症は進行が速やかで極めて予後不良である. Mott は文献上経過があきらかな 14 例のらち， 1 年以上生存 は 3 例にすぎないと報告している。本症例に揖いては 症状初発 5 カ月後には腹部大血管分岐部を越えるリン パ節転移を認め, 初診より10カ月後に死亡した.

本症に対しては特に有効な治療法はない。抗男性木 ルモン療法は無効である。文献上治療が奏効したとさ れるのは, 放射線療法にて 9 年間生存した 1 例 ${ }^{13)}$, 肺転 移に対し Adriamycin が著効を示した 1 例 ${ }^{14)} 2$ 例だ けである。本症における malignant potential は極め て高いので，集学的治療が必要であろう。本症例では ペプロマイシン $10 \mathrm{mg} \times 7$ 回，5-FU $1,000 \mathrm{mg} \times 82$ 回投 与したが効果はなかった。化学療法を施行するならば Adriamycin や頭頸部の扁平上皮癌に有効とされる Cis-DDP ${ }^{15)}$ な゙を加えての多剤併用療法が望ましい。 放射線療法も単独では必ずしも有効とはいい難く手術 療法に併用すべきであろら. 本症例や $\mathrm{Gray}^{16)}$ らの症例 の上5に本症は局所再発をさたしやすいと思われ，又 尿路上皮由来といらことも否定できないため，前立腺 全摘術よりも膀胱前立腺全摘術を施行し，さらに局所 に対し放射線療法を抏こならのが望ましいと思われ た。

\section{結 語}

前立腺扁平上皮癌は極めて稀な疾患であり，予後不 良とされている。我々は本症の 1 例を報告するととも に若干の文献的考察を行った。

本論文の要旨は第141回東海泌尿器科学会に招いて発表 した。

\section{文献}

1）河崎屋三郎, 白崎幸雄, 小坂信生：前立腺扁平上皮 癌。癌の臨床，5，101-105, 1959。

2）畑 昌宏。太田信隆，大見嘉郎，鈴木和雄，田島 惇, 藤田公生, 阿曾佳郎：前立腺扁平上皮癌の 1 例。日尿泌，72，1511，1981。

3）佐々木信之, 猪要忠治, 竹中生昌：前立腺扁平上皮 
癌の 1 例. 日泌尿, 74, 265, 1983.

4）佐藤公繁, 荒尾龍喜：腺癌及び扁平上皮癌の混在 する前立腺原発癌と思われる 1 剖検例. 臨床皮泌, 9, 621-625, 1955.

5) Kahler, J.E.: Carcinoma of the prostate gland: A pathologic study. J. Urol., 41, 557-574, 1939.

6) Arnheim, F.K.: Carcinoma of the prostate : A study of the postmortem findings in one hundred and seventy-six cases. J. Urol., 60, 599-603, 1948.

7) Melicow, M.M.: Cancer of the prostate concepts and guidelines in histologic diagnosis. J. Urol., 95, 791, 1966.

8) Mott, L.J.M.: Squamous cell carcinoma of the prostate: Report of 2 cases and review of the literature. J. Urol., 121, 833-835, 1979.

9) Mostofi, F.K. ad Price, E.B. Jr.: Tumors of the male genital system, In: Atlas of Tumor Pathology, Washington, D.C. : Armed Forces Institute of Pathology, Fasc, 8, 190-192, 1973.

10）川井修一, 徳原正洋: 前立腺癌 (ductal origin) の一例．西日泌尿，44，823-827，1982.
11）岡部 勉, 野田進士, 江藤耕作, 入江康司：前立腺 原発性移行上皮癌の 1 例. 西日泌尿, 43, 963-967, 1981.

12) Thompson, G.J. and Albers, D.D.: Unusual carcinomas involving prostate gland. J. rol., 69, 416-425, 1953.

13) Sieracki, J.C.: Epidermiod carcinoma of the human prostate: Report of three cases. Lab. Invest., 4, 232-240, 1955.

14) Corder, M.P. and Cicmil, G.A. : Effective treatment of metastatic squamous cell carcinoma of the prostate with adriamycin. J. Urol., 115, 222, 1976.

15) Brown, A.W. Jr., Blom, J., Butler, W.M., Garcia-Guerrero, G., Richardson, M.F. and Henderson, R.L.: Combination chemotherapy with Vinblastine, Bleomycin and Cis-diamminedichloroplatinum (II) in squamous cell carcinoma of the head and neck. Cancer, 45, 2830-2835, 1980.

16) Gray, G.F. and Marshall, V.F.: Squamous carcinoma of athe prostate. J. Urol., 113, 736-738, 1975,

（1983年12月 17 日受付） 